\title{
Digestible lysine levels in diets for laying Japanese quails
}

\author{
Cleverson Luís Nascimento Ribeiro', Sergio Luiz de Toledo Barreto', Renata de Souza Reis", \\ Jorge Cunha Lima Muniz', Juarez Lopes Donzele ${ }^{1}$, Paulo Cezar Gomes ${ }^{1}$, José Geraldo de \\ Vargas Júnior ${ }^{2}$, Luiz Fernando Teixeira Albino ${ }^{1}$
}

\footnotetext{
${ }^{1}$ Department of Animal Science, UFV, Viçosa/MG, Brazil.

${ }^{2}$ Department of Animal Science, UFES, Alegre/ES, Brazil.
}

\begin{abstract}
The objective of this study was to estimate the digestible lysine requirement of Japanese quails in the egg-laying phase. A total of 336 female Japanese quails (Coturnix coturnix japonica) of average initial age of 207 days were distributed in a completely randomized experimental design, composed of 6 treatments (lysine levels) with 7 replicates and 8 birds per experimental unit, with duration of 84 days. Experimental diets were formulated from a basal diet, with corn and soybean meal, with $2.800 \mathrm{kcal} \mathrm{ME} / \mathrm{kg}$ and $203.70 \mathrm{~g} / \mathrm{kg}$ crude protein, showing levels of $9.50 ; 10.00 ; 10.50 ; 11.00 ; 11.50 ;$ and $12.00 \mathrm{~g} / \mathrm{kg}$ digestible lysine; diets remained isoprotein and isocaloric. The following variables were studied: feed intake (FI); lysine intake (LI); egg production per bird per day (EPBD); egg production per bird housed (EPBH); production of marketable eggs (PME); egg weight (EW); egg mass (EM); utilization efficiency of lysine for egg mass production (UELEM); feed conversion per mass (FCEM); feed conversion per dozen eggs (FCDZ); bird availability (BA); percentages of yolk (Y), albumen (A) and shell (S); specific egg weight (SW); nitrogen ingested (NI); nitrogen excreted (NE); and nitrogen balance (NB). Significant effect was only observed for LI, EW, EM, UELEM, FCEM, Y, A and SW. The digestible lysine level estimated in diets for laying Japanese quails is $11.20 \mathrm{~g}$ digestible lysine/ $\mathrm{kg}$ diet, corresponding to an average daily intake of $272.23 \mathrm{mg}$ lysine.
\end{abstract}

Key Words: Coturnix coturnix japonica, digestible amino acids, egg production, performance variables

\section{Introduction}

Quail raising has stood out in the aviculture sector, especially for egg production, for being extremely attractive and profitable for the Brazilian agribusiness, which makes it a good option, be it for small or big farmers.

The advancements in the knowledge of the nutritional requirements of birds, at their many phases, has constantly brought improvement to the quality of the diet; firstly in the sense of reaching maximum production, followed by the search for the lowest price of the feed and for the conversion of these animals into egg numbers (Ceccantini \& Yuri, 2008).Thus, the great knowledge of the metabolism of protein in birds and the production of amino acids on a commercial basis have enabled the utilization of the concept of ideal protein at the formulation of diets.

This concept can be defined, theoretically, as the exact balance of the amino acids in the diet capable of meeting, without excess or deficiency, the requirements of all the essential amino acids for production and maintenance of birds, expressing them as percentage in relation to the lysine which is adopted as reference amino acid.
Lysine is the second limiting amino acid in diets for birds; its use, in lower or excessive levels, regarding the nutritional requirement of this nutrient in birds, may bring metabolic damages, which could compromise bird performance (Kidd \& Kerr, 1998).

For many decades, studies on the utilization of lysine, based on the concept of ideal protein in the diets of birds, have been developed, because of the great applicability, ease of utilization in the formulation of diets and low costs of the acquisition of L-lysine- $\mathrm{HCl}$; however, in quail raising, these studies are recent.

Estimating the digestible lysine requirement for Japanese quails at laying, Pinto et al. (2003) suggested the level of $11.17 \mathrm{~g}$ digestible lysine $/ \mathrm{kg}$ of diet for diets containing $195.60 \mathrm{~g}$ crude protein (CP)/kg of diet. Rodrigues et al. (2007) evaluated the digestible lysine nutritional requirements in diets for Japanese quails in the laying phase and concluded that the digestible lysine requirement was $10.30 \mathrm{~g} / \mathrm{kg}$ of the diet. Assessing the digestible lysine nutritional requirement in diets for Japanese quails in the laying phase containing $195.0 \mathrm{~g} \mathrm{CP} / \mathrm{kg}$ of diet, Demuner et al. (2009a) concluded that the digestible lysine requirement estimated was $10.90 \mathrm{~g} / \mathrm{kg}$ of diet. 
The objective with this research was to estimate the digestible lysine level in diets for Japanese quails during the egg-laying phase.

\section{Material and Methods}

A total of 336 female quails of the Japanese subspecies Coturnix coturnix japonica of 207 days of age with initial body weight of $179.82 \pm 0.73 \mathrm{~g}$ were distributed in a completely randomized experimental design composed of six treatments (lysine levels), with seven replicates and eight birds per experimental unit. The experiment lasted 84 days. Birds were housed in galvanized wire cages equipped with nipple drinkers and trough feeder, at an animal density of $106 \mathrm{~cm}^{2} /$ bird per experimental unit.

The lighting program was of 16 daily hours and maximum and minimum temperatures were measured once daily at $8 \mathrm{~h} 00$; relative air humidity of the facility was measured twice daily, at $8 \mathrm{~h} 00$ and $16 \mathrm{~h} 00$, with maximum minimum thermometers and dry and wet bulb thermometers, placed at the center of the shed, at the height of birds.

Water and feed were supplied ad libitum. Feed was supplied twice daily, aiming at avoiding waste. Collection and counting of eggs were performed every day, in the morning.

Experimental diets were formulated to meet quail nutritional requirements, following recommendations of the NRC (1994), except for amino acids ratios: threonine $(55 \%)$, digestible tryptophan (21\%), digestible methionine + cystine $(84 \%)$, digestible arginine $(1.16 \%)$, digestible valine (75\%) and digestible isoleucine (65\%), which were based, respectively, on the recommendations of Umigi et al. (2008), Pinheiro (2006), Reis (2009), Reis et al. (2010), Paula et al. (2010a) and Paula et al. (2010b). These diets were elaborated from a basal one containing $2800 \mathrm{kcal}$ metabolizable energy (ME)/kg, as determined by Moura (2007) and $203.70 \mathrm{~g} \mathrm{CP} / \mathrm{kg}$ of diet, utilizing corn and soybean meal, supplemented with L-lysine $\mathrm{HCl}$, substituting glutamic acid, in protein equivalent, to keep the $9.50 ; 10.00 ; 10.50 ; 11.00 ; 11.50$; and $12.00 \mathrm{~g}$ levels of digestible lysine $/ \mathrm{kg}$ of diet; all diets were formulated with the same protein and calorie level (Table 1). The differences due to balancing for protein equivalents of lysine and glutamic acid at the different lysine levels under evaluation were compensated by starch.

The digestible lysine levels utilized in the formulation of diets were based on studies with broilers. There are no sufficient studies to determine feedstuff digestibility of amino acids with quail use. Thus, the composition, the nutritional values and the digestibility values of the ingredients utilized in the formulation of diets were according to Rostagno et al. (2005).
The following performance variables were evaluated: feed intake ( $\mathrm{g} /$ bird.day), lysine intake ( $\mathrm{mg} /$ bird.day), egg production per bird per day (\%), egg production per bird housed (\%), egg weight ( $\mathrm{g}$ ), egg mass (g/bird.day), utilization efficiency of lysine for egg mass production (egg mass/digestible lysine intake, expressed in grams of mass produced per grams of digestible lysine intake), feed conversion per egg mass ( $\mathrm{kg}$ of diet $/ \mathrm{kg}$ of eggs) and per dozen eggs ( $\mathrm{kg}$ of diet/egg dz), bird availability (total dead birds - total live birds $\times 100$ ), nitrogen ingested (g), nitrogen excreted $(\mathrm{g})$ and nitrogen balance $(\mathrm{g})$.

As for the variables of internal and external egg quality, these were assessed: production of marketable eggs (total intact eggs/total eggs produced $\times 100$ ) yolk weight $(\mathrm{g})$, yolk percentage (\%), albumen weight (g), albumen percentage $(\%)$, eggshell weight $(\mathrm{g})$, eggshell percentage $(\%)$ and specific egg weight $\left(\mathrm{g} / \mathrm{cm}^{3}\right)$.

For quantification of egg components, four eggs of each experimental unit were randomly collected on the 19th, 20th, 21st, 40th, 41st, 42nd, 61st, 62nd, 63rd, 82nd, 83rd and 84th days of the experimental period (84 days). Eggs were weighed individually on a $0.001 \mathrm{~g}$ precision scale. After weighing, eggs were identified and cracked. The yolk of each egg was weighed, and its shell was washed and dried in the air, for determination of its weight; albumen weight was calculated by the difference between egg weight and yolk weight plus eggshell weight.

Specific egg weight was determined through immersion of all intact eggs collected into $\mathrm{NaCl}$ solutions with densities varying from 1.055 to $1.090 \mathrm{~g} / \mathrm{cm}^{3}$, with $0.005 \mathrm{~g} / \mathrm{cm}^{3}$ intervals and evaluated for density or specific egg weight, by the Archimedes principle (Thompson \& Hamilton, 1982; Yannakopoulos \& Tserveni-Gousi, 1986).

For the estimate of nitrogen balance, at the end of the experimental period, in four randomly chosen replicates of each treatment, eight birds were housed in galvanized wire cages on a battery pattern, provided with trough feeders and drinkers, on galvanized metal sheet and PVC, respectively, and galvanized metal sheet tray coated with plastic, for the collection of excreta. Birds were subjected to an experimental adaptation period of three days, and right after, excreta collection started, twice a day, for three consecutive days; excreta were stored in freezer. After collection period, the material was weighed, homogenized and samples were taken and dried in an oven. Feed intake in the collection period was recorded and experimental diets corresponding to each experimental unit were sampled for further laboratory analyses.

Analyses of dry matter and total nitrogen, experimental diets and excreta collected were performed according to 
Table 1 - Composition of experimental diets ( $\mathrm{g} / \mathrm{kg}$ as fed)

\begin{tabular}{|c|c|c|c|c|c|c|}
\hline \multirow{2}{*}{ Ingredients } & \multicolumn{6}{|c|}{ Lysine level (g of lysine/kg of diet) } \\
\hline & 9.50 & 10.00 & 10.50 & 11.00 & 11.50 & 12.00 \\
\hline Corn & 560.86 & 560.86 & 560.86 & 560.86 & 560.86 & 560.86 \\
\hline Soybean meal ( $45 \%$ crude protein) & 326.29 & 326.29 & 326.29 & 326.29 & 326.29 & 326.29 \\
\hline Corn starch & 1.00 & 1.34 & 1.69 & 2.78 & 4.64 & 6.53 \\
\hline Glutamic acid & 14.00 & 12.65 & 11.19 & 8.65 & 4.68 & 0.60 \\
\hline L-lysine $\mathrm{HCl}(79 \%)$ & 0.00 & 0.63 & 1.27 & 1.90 & 2.53 & 3.17 \\
\hline DL-methionine (99\%) & 2.55 & 2.93 & 3.35 & 3.77 & 4.19 & 4.61 \\
\hline L-tryptophan (99\%) & 0.00 & 0.00 & 0.05 & 0.15 & 0.26 & 0.36 \\
\hline L-arginine (99\%) & 0.00 & 0.00 & 0.00 & 0.30 & 0.88 & 1.46 \\
\hline L-valine $(99 \%)$ & 0.00 & 0.00 & 0.00 & 0.00 & 0.37 & 0.74 \\
\hline L-isoleucine (99\%) & 0.00 & 0.00 & 0.00 & 0.00 & 0.00 & 0.08 \\
\hline Soybean oil & 12.60 & 12.60 & 12.60 & 12.60 & 12.60 & 12.60 \\
\hline Limestone & 66.27 & 66.27 & 66.27 & 66.27 & 66.27 & 66.27 \\
\hline Dicalcium phosphate & 10.62 & 10.62 & 10.62 & 10.62 & 10.62 & 10.62 \\
\hline Salt & 3.21 & 3.21 & 3.21 & 3.21 & 3.21 & 3.21 \\
\hline Choline chloride $(60 \%)$ & 1.00 & 1.00 & 1.00 & 1.00 & 1.00 & 1.00 \\
\hline Mineral premix $^{1}$ & 0.50 & 0.50 & 0.50 & 0.50 & 0.50 & 0.50 \\
\hline Vitamin premix ${ }^{2}$ & 1.00 & 1.00 & 1.00 & 1.00 & 1.00 & 1.00 \\
\hline Antioxidant ${ }^{3}$ & 0.10 & 0.10 & 0.10 & 0.10 & 0.10 & 0.10 \\
\hline Total & 1000.00 & 1000.00 & 1000.00 & 1000.00 & 1000,00 & 1000,00 \\
\hline \multicolumn{7}{|l|}{ Calculated composition } \\
\hline Metabolizable energy (kcal/kg) & 2.800 & 2.800 & 2.800 & 2.800 & 2.800 & 2.800 \\
\hline Crude protein $(\mathrm{g} / \mathrm{kg})$ & 203.70 & 203.70 & 203.70 & 203.70 & 203.70 & 203.70 \\
\hline Digestible lysine (g/kg) & 9.50 & 10.00 & 10.50 & 11.00 & 11.50 & 12.00 \\
\hline Digestible methionine + cystine $(\mathrm{g} / \mathrm{kg})$ & 7.98 & 8.40 & 8.82 & 9.24 & 9.66 & 10.08 \\
\hline Digestible threonine $(\mathrm{g} / \mathrm{kg})$ & 6.64 & 6.64 & 6.64 & 6.64 & 6.64 & 6.64 \\
\hline Digestible tryptophan (g/kg) & 2.16 & 2.16 & 2.21 & 2.31 & 2.42 & 2.52 \\
\hline Digestible valine $(\mathrm{g} / \mathrm{kg})$ & 8.24 & 8.24 & 8.24 & 8.24 & 8.63 & 9.00 \\
\hline Digestible isoleucine (g/kg) & 7.72 & 7.72 & 7.72 & 7.72 & 7.72 & 7.80 \\
\hline Digestible arginine $(\mathrm{g} / \mathrm{kg})$ & 12.46 & 12.46 & 12.46 & 12.76 & 13.34 & 13.92 \\
\hline Total phenylalanine + tyrosine $(\mathrm{g} / \mathrm{kg})$ & 16.46 & 16.46 & 16.46 & 16.46 & 16.46 & 16.46 \\
\hline Total histidine $(\mathrm{g} / \mathrm{kg})$ & 5.28 & 5.28 & 5.28 & 5.28 & 5.28 & 5.28 \\
\hline Total glycine + serine $(\mathrm{g} / \mathrm{kg})$ & 17.83 & 17.83 & 17.83 & 17.83 & 17.83 & 17.83 \\
\hline Available phosphorus (g/kg) & 3.00 & 3.00 & 3.00 & 3.00 & 3.00 & 3.00 \\
\hline Calcium $(\mathrm{g} / \mathrm{kg})$ & 29.00 & 29.00 & 29.00 & 29.00 & 29.00 & 29.00 \\
\hline Sodium (g/kg) & 1.45 & 1.45 & 1.45 & 1.45 & 1.45 & 1.45 \\
\hline Crude fiber (g/kg) & 27.40 & 27.40 & 27.40 & 27.40 & 27.40 & 27.40 \\
\hline
\end{tabular}

the methodology described by Silva \& Queiroz (2002). Nitrogen balance was calculated by the difference between the amount of nitrogen excreted and ingested by quails.

The data were analyzed on software SAEG (Sistema para Análises Estatísticas e Genéticas, version 9.1), developed at Universidade Federal de Viçosa, 2007, by means of procedures for variance and regression analyses. The study adopted $\alpha=0.05$.

\section{Results and Discussion}

The maximum average temperature reached was $30.56 \pm 3.2{ }^{\circ} \mathrm{C}$, and the minimum was $20.03 \pm 0.92{ }^{\circ} \mathrm{C}$. The average relative air humidity was $80.4 \pm 2.6 \%$ in the morning and $69.9 \pm 6.4 \%$ in the afternoon. In the adult phase, the thermal comfort range or thermoneutral zone of quails is between 18 and $22{ }^{\circ} \mathrm{C}$ and the relative air humidity, between 65 and $70 \%$ (Oliveira, 2004). Thus, according to the values recorded for average air temperature and relative air humidity, throughout the experiment, quails underwent periods of heat stress.

The digestible lysine levels did not affect $(\mathrm{P}>0.05)$ feed intake (Table 2); these results are similar to those found by Ribeiro et al. (2003) and Demuner et al. (2009a), who worked with Japanese quails in the laying phase. On the other hand, the results found do not corroborate those obtained by Rodrigues et al. (2007), who, evaluating five levels $(8.80 ; 9.60 ; 10.40 ; 11.20$; and $12.00 \mathrm{~g})$ of digestible lysine $/ \mathrm{kg}$ of diet for Japanese quails in the egg-laying phase, observed quadratic effect on feed intake. These authors explained that the increase in digestible lysine levels in the diet elevated feed intake. 
Linear increase $(\mathrm{P}<0.05)$ was verified in digestible lysine intake as its concentration in the diet rose (Table 2); among the levels studied ( $9.50-12.00 \mathrm{~g}$ digestible lysine $/ \mathrm{kg}$ of diet), every $0.50 \mathrm{~g}$ digestible lysine $/ \mathrm{kg}$ of diet increased digestible lysine intake by $12.98 \mathrm{mg}$. These results are similar to those found by Pinto et al. (2003) and Rodrigues et al. (2007), who found linear increase of 25.8 and $21.7 \mathrm{mg}$ in lysine intake for every $1.00 \mathrm{~g}$ digestible lysine $/ \mathrm{kg}$ of diet increase, respectively.

Egg production per bird per day and per bird housed and production of marketable eggs were not affected $(\mathrm{P}>0.05)$ by the digestible lysine levels in the diets (Table 2 ). These results are similar to those found by Demuner et al. (2009 a,b), who evaluated the nutritional requirements of digestible lysine for Japanese quails at the laying phase. However, the values achieved are not in accordance with those presented by Rodrigues et al. (2007), who defined the level of $10.30 \mathrm{~g}$ digestible lysine $/ \mathrm{kg}$ of diet, which resulted in higher percentages in the egg production of Japanese quails.

The digestible lysine levels utilized in experimental diets showed quadratic effect $(\mathrm{P}<0.05)$ for egg weight; the level of $11.20 \mathrm{~g}$ digestible lysine $/ \mathrm{kg}$ of diet promoted the highest egg weight (Table 2). The results obtained in the present study are in agreement with those found by Oliveira et al. (1999), Pinto et al. (2003), Ribeiro et al. (2003) and Demuner et al. (2009b), who verified higher results for egg weight from Japanese quails as they increased the lysine level in the diet. For their part, Garcia et al. (2005), Rodrigues et al. (2007) and Demuner et al. (2009a) did not verify changes in egg weight of Japanese quails resulting from the increase in the lysine level in the diet.
Egg mass also varied $(\mathrm{P}<0.05)$ with digestible lysine levels; it increased quadratically up to the estimated level of $11.20 \mathrm{~g}$ digestible lysine $/ \mathrm{kg}$ of diet (Table 2). The result achieved is consistent with those observed by Pinto et al. (2003), where the level of $11.17 \mathrm{~g}$ digestible lysine $/ \mathrm{kg}$ of diet was the one which maximized egg mass. Contrarily, Ribeiro et al. (2003), Rodrigues et al. (2007) and Demuner et al. (2009a) did not verify effect of digestible lysine levels on the egg mass of Japanese quails. Since egg production did not vary between the treatments, the response pattern of egg mass is directly linked to the egg weight results.

In accordance with the results obtained for digestible lysine intake (Table 2), utilization efficiency of digestible lysine for egg mass production reduced linearly $(\mathrm{P}<0.05)$ as the concentration of digestible lysine in the diet increased. Taking only the extreme digestible lysine levels analyzed ( 9.50 and $12.00 \mathrm{~g}$ digestible lysine $/ \mathrm{kg}$ of diet), the intake of one gram digestible lysine resulted in respective production of 42.0 and $34.6 \mathrm{~g}$ egg mass. Brumano (2008), who worked with white-egg-laying hens in the period from 42 to 58 weeks of age, observed quadratic effect of the digestible methionine + cistine to lysine utilization efficiency on total egg production.

Feed conversion per egg mass varied quadratically $(\mathrm{P}<0.05)$ with increase in lysine levels; it increased up to the estimated level of $11.20 \mathrm{~g}$ digestible lysine $/ \mathrm{kg}$ of diet (Table 2). Corroborating this result, Pinto et al. (2003) and Demuner et al. (2009a) also verified positive influence of digestible lysine on feed conversion per egg mass of Japanese quails in the egg-laying phase; the best responses were obtained at levels 10.50 and $10.90 \mathrm{~g}$ digestible lysine $/ \mathrm{kg}$ of diet, respectively.

Table 2 - Influence of digestible lysine level on performance variables in Japanese laying quails

\begin{tabular}{|c|c|c|c|c|c|c|c|c|c|c|}
\hline \multirow{2}{*}{ Variable } & \multicolumn{6}{|c|}{ Digestible lysine levels (g/kg of NM) } & \multicolumn{3}{|c|}{ P-value } & \multirow{2}{*}{$\mathrm{CV}(\%)$} \\
\hline & 9.50 & 10.00 & 10.50 & 11.00 & 11.50 & 12.00 & Linear & Quadratic & Lack of fit & \\
\hline FI (g/bird.day) & 23.82 & 24.01 & 24.57 & 24.59 & 23.85 & 24.51 & 0.225 & 0.288 & 0.025 & 3.14 \\
\hline LI (mg/bird.day) ${ }^{1}$ & 226.33 & 240.09 & 257.98 & 270.51 & 274.32 & 294.10 & 0.001 & 0.370 & 0.022 & 3.20 \\
\hline EPBD $(\%)$ & 86.04 & 86.74 & 88.45 & 89.93 & 85.58 & 89.22 & 0.318 & 0.529 & 0.040 & 4.93 \\
\hline ЕРВН (\%) & 79.66 & 82.74 & 83.33 & 85.27 & 80.68 & 83.38 & 0.576 & 0.423 & 0.273 & 9.78 \\
\hline PME (\%) & 98.01 & 97.28 & 98.29 & 98.64 & 97.97 & 97.43 & 0.910 & 0.239 & 0.074 & 1.41 \\
\hline $\mathrm{EW}(\mathrm{g})^{2}$ & 10.92 & 11.26 & 11.34 & 11.51 & 11.53 & 11.35 & 0.003 & 0.011 & 0.435 & 2.75 \\
\hline EM (g/bird.day $)^{3}$ & 9.38 & 9.75 & 10.04 & 10.34 & 9.86 & 10.12 & 0.079 & 0.048 & 0.600 & 4.75 \\
\hline $\operatorname{UELEM}(\mathrm{g} / \mathrm{g})^{4}$ & 42.03 & 41.04 & 39.29 & 38.59 & 36.15 & 34.68 & 0.001 & 0.443 & 0.370 & 4.96 \\
\hline FCEM $(\mathrm{kg} / \mathrm{kg})^{5}$ & 2.48 & 2.38 & 2.36 & 2.26 & 2.29 & 2.34 & 0.006 & 0.027 & 0.256 & 5.02 \\
\hline FCDZ (kg/dz) & 0.331 & 0.335 & 0.336 & 0.328 & 0.339 & 0.334 & 0.701 & 0.950 & 0.250 & 5.77 \\
\hline $\mathrm{BA}(\%)$ & 89.29 & 93.23 & 93.23 & 93.75 & 93.75 & 91.52 & 0.581 & 0.244 & 0.658 & 8.14 \\
\hline
\end{tabular}

NM - natural matter; CV - coefficient of variation; FI - feed intake; LI - digestible lysine intake; EPBD - egg production per bird per day; EPBH - egg production per bird housed; PME - production of marketable eggs; EW - egg weight; EM - egg mass; UELEM - utilization efficiency of digestible lysine for egg mass production; FCEM - feed conversion per egg mass; FCDZ - feed conversion per egg dozen; BA - bird availability.

${ }^{1} \hat{\mathrm{Y}}=-18.364+25.9458 \times \mathrm{X}\left(\mathrm{R}^{2}=0.98\right)$.

${ }^{2} \hat{Y}=-14.238+4.6026 \times X-0.20572 \times X^{2}\left(R^{2}=0.97\right)$

${ }^{3} \hat{Y}=8.8927+0.05697 \times X-0.00064 \times X^{2}\left(R^{2}=0.69\right)$

${ }^{4} \hat{\mathrm{Y}}=70.635-2.9774 \times \mathrm{X}\left(\mathrm{R}^{2}=0.98\right)$.

${ }^{5} \hat{Y}=10.773-1.5142 \times X+0.06754 \times X^{2}\left(R^{2}=0.91\right)$. 
No effect of digestible lysine levels was verified $(\mathrm{P}>0.05)$ on feed conversion per dozen eggs (Table 2). Likewise, Oliveira et al. (1999), Ribeiro et al. (2003), Rodrigues et al. (2007) and Demuner et al. (2009b) did not find effect of digestible lysine levels on the same variable. The fact that feed intake and egg production per bird per day or per bird housed did not vary by treatment explains the results obtained for feed conversion per dozen eggs.

Bird availability was not affected $(\mathrm{P}>0.05)$ by digestible lysine levels in the diets (Table 2), still presenting a mortality rate in the experimental period of $7.6 \%$, corresponding to the weekly mortality of $0.63 \%$. Although bird availability was not altered in between treatments, the average weekly mortality value of $0.63 \%$ in this study is considered high for the standards of this species. Analyzing data from 26 Japanese quail commercial raising broods, Oliveira (2007) found weekly mortality of $0.49 \%$. A possible explanation for this higher mortality rate could be the temperature and air humidity effect, which were above the values of the thermal comfort range, which might have contributed to the discomfort of birds.

For yolk, quadratic effect $(\mathrm{P}<0.05)$ was observed in relation to the digestible lysine levels in the diets (Table 3). Reis et al. (2006), working with the total lysine nutritional requirement of European quails at egg-laying, assessing the levels of $8.50 ; 9.50 ; 10.50 ; 11.50$; and $12.50 \mathrm{~g}$ digestible lysine $/ \mathrm{kg}$ of diet, verified linear increase for yolk as the lysine levels in the diet increased. Different results were observed by Ribeiro (2003) and Rodrigues et al. (2007), who did not find any effect of digestible lysine levels on the yolk weight of Japanese quail eggs.

Quadratic effect $(\mathrm{P}<0.05)$ of digestible lysine levels was observed on albumen (Table 3). These results are in accordance with those found by Cupertino (2006), who, assessing the digestible lysine nutritional requirement of laying hens from 54 to 70 weeks of age, obtained increasing linear effect of digestible lysine levels on the quantity of egg albumen. On the other hand, the results obtained by Ribeiro et al. (2003), Reis et al. (2006) and Rodrigues et al. (2007) did not show effect of lysine levels on albumen in quail eggs.

No effect $(\mathrm{P}>0.05)$ of digestible lysine levels related to eggshell or percentages of yolk, albumen and shell was observed. The results corroborate those found by Ribeiro et al. (2003) and Rodrigues et al. (2007).

There was quadratic effect $(\mathrm{P}<0.05)$ of digestible lysine levels on specific egg weight (Table 3 ). The level of $10.90 \mathrm{~g}$ digestible lysine $/ \mathrm{kg}$ of diet resulted in $1.072 \mathrm{~g} / \mathrm{cm}^{3}$, enabling the occurrence of eggs with lower shell quality as compared with other levels of lysine studied. However, in studies conducted by Rodrigues et al. (2007), the digestible lysine levels did not have effect on specific egg weight of Japanese quails. Nevertheless, even showing a $0.19 \%$ variation between the highest specific egg weight $\left(1.074 \mathrm{~g} / \mathrm{cm}^{3}\right)$ and the lowest specific egg weight $\left(1.072 \mathrm{~g} / \mathrm{cm}^{3}\right)$, which could result in eggs with thinner shell, we can observe that there was no interference with eggshell quality, which can be confirmed by the production of marketable eggs, which, in absolute values, presented the greatest percentage (98.64\%), close to the level estimated for the highest egg weight (11.20 $\mathrm{g}$ digestible lysine $/ \mathrm{kg}$ of diet).

Likewise, according to the equation obtained, the level of $11.20 \mathrm{~g}$ of lysine $/ \mathrm{kg}$ of diet resulted in higher egg mass, obtained from the higher egg weight and a high egg production per bird per day, which possibly could have contributed to a worse specific egg weight, but not interfering with production of marketable eggs, which was also kept high.

Digestible lysine levels did not affect $(\mathrm{P}>0.05)$ nitrogen intake, nitrogen excretion or nitrogen balance (Table 4). These results are similar to those achieved by Matos et al. (2009). They suggested that the amount of nitrogen excreted by the organism for maintenance and egg production was met by birds in all experimental groups.

Table 3 - Digestible lysine levels on weight and percentage of yolk, albumen, shell and specific egg weight (SW) of Japanese laying quails

\begin{tabular}{|c|c|c|c|c|c|c|c|c|c|c|}
\hline \multirow{2}{*}{ Variable } & \multicolumn{6}{|c|}{ Digestible lysine levels (g/kg of NM) } & \multicolumn{3}{|c|}{ P-value } & \multirow{2}{*}{$\mathrm{CV}(\%)$} \\
\hline & 9.50 & 10.00 & 10.50 & 11.00 & 11.50 & 12.00 & Linear & Quadratic & Lack of fit & \\
\hline Yolk $(g)^{1}$ & 3.29 & 3.47 & 3.47 & 3.48 & 3.46 & 3.49 & 0.004 & 0.032 & 0.034 & 3.08 \\
\hline Albumen $(g)^{2}$ & 6.97 & 7.06 & 7.19 & 7.36 & 7.23 & 7.19 & 0.005 & 0.012 & 0.102 & 2.59 \\
\hline Shell (g) & 0.872 & 0.912 & 0.902 & 0.907 & 0.895 & 0.916 & 0.060 & 0.285 & 0.014 & 2.97 \\
\hline Yolk (\%) & 29.50 & 30.31 & 29.97 & 29.62 & 29.84 & 30.12 & 0.516 & 0.868 & 0.009 & 2.14 \\
\hline Albumen (\%) & 62.65 & 61.71 & 62.22 & 62.65 & 62.43 & 61.97 & 0.705 & 0.818 & 0.002 & 1.07 \\
\hline Shell (\%) & 7.85 & 7.98 & 7.81 & 7.73 & 7.73 & 7.91 & 0.433 & 0.170 & 0.013 & 2.21 \\
\hline $\mathrm{SW}\left(\mathrm{g} / \mathrm{cm}^{3}\right)^{3}$ & 1.074 & 1.073 & 1.073 & 1.072 & 1.072 & 1.073 & 0.074 & 0.001 & 0.047 & 0.06 \\
\hline
\end{tabular}

$\mathrm{NM}$ - natural matter; $\mathrm{CV}$ - coefficient of variation.

${ }^{1} \hat{Y}=-3.918+1.3194 \times X-0.05868 \times X^{2}\left(R^{2}=0.76\right)$.

${ }^{2} \hat{Y}=-7.922+2.7245 \times X-0.12210 \times X^{2}\left(R^{2}=0.86\right)$.

${ }^{3} \hat{Y}=1.141-0.0126 \times X+0.000574 \times X^{2}\left(R^{2}=0.80\right)$ 
Table 4 - Digestible lysine levels on the values of nitrogen ingested, nitrogen excreted and nitrogen balance of laying Japanese quails

\begin{tabular}{lcccccccccc}
\hline \multirow{2}{*}{ Variable } & \multicolumn{4}{c}{ Digestible lysine levels $(\mathrm{g} / \mathrm{kg}$ of NM) } & \multicolumn{3}{c}{ P-value } \\
\cline { 2 - 8 } & 9.50 & 10.00 & 10.50 & 11.00 & 11.50 & 12.00 & Linear & Quadratic & Lack of fit & $0.1 \%$ ) \\
\hline Nitrogen ingested (g) & 0.680 & 0.701 & 0.698 & 0.719 & 0.702 & 0.703 & 0.104 & 0.083 & 0.146 & 2.69 \\
Nitrogen excreted (g) & 0.127 & 0.122 & 0.125 & 0.120 & 0.130 & 0.124 & 0.939 & 0.670 & 0.183 & 9.05 \\
Nitrogen balance (g) & 0.553 & 0.580 & 0.574 & 0.598 & 0.572 & 0.579 & 0.149 & 0.074 & 0.057 & 3.61 \\
\hline
\end{tabular}

$\mathrm{NM}$ - natural matter; CV - coefficient of variation.

The level of $11.20 \mathrm{~g}$ digestible lysine/kg of diet increased egg weight, egg mass, feed conversion per egg mass, yolk weight and albumen weight, which demonstrates that this level promoted satisfactory results on Japanese quail performance and egg quality.

\section{Conclusions}

The digestible lysine level estimated in diets for Japanese quails in the egg-laying phase was $11.20 \mathrm{~g}$ digestible lysine $/ \mathrm{kg}$ of diet, corresponding to a daily intake of $273.23 \mathrm{mg}$ digestible lysine/bird or $26.61 \mathrm{mg}$ digestible lysine/g of egg mass.

\section{References}

BRUMANO, G. Níveis de metionina + cistina digestíveis em rações para poedeiras leves no período de 24 a 40 e de 42 a 58 semanas de idade. 2008. 103f. Tese (Doutorado em Zootecnia) - Universidade Federal de Viçosa, Viçosa, MG.

CECCANTINI, M.L.; YURI, D. Otimização da formulação de ração para poedeiras com base em aminoácidos digestíveis. In: CURSO DE ATUALIZAÇÃO EM AVICULTURA DE POSTURA COMERCIAL, 5., 2008 Jaboticabal. Anais... Jaboticabal, 2008. p.31-40.

CUPERTINO, E.S.; GOMES, P.C.; ALBINO, L.F.T. et al. Exigências nutricionais de lisina, de metionina + cistina e de treonina para galinhas poedeiras no período de 54 a 70 semanas de idade. 2006. 134f. Tese (Doutorado em Zootecnia) - Universidade Federal de Viçosa, Viçosa, MG.

DEMUNER, L.F.; VARGAS, J.G.; SCOTTÁ, B.A. et al. Níveis nutricionais de lisina digestível para codornas japonesas alimentadas com rações contendo $19,5 \%$ de proteína bruta. In: ZOOTEC 2009, ASSOCIAÇÃO BRASILEIRA DE ZOOTECNISTAS, 5. Águas de Lindóia. Anais... Águas de Lindóia: ZOOTEC, 2009a. Available at: <http://www.abz.org.br> Accessed on: Apr. 14, 2011.

DEMUNER, L.F.; VARGAS, J.G.; PETRUCCI, F.B. et al. Níveis nutricionais de lisina digestível em rações de codornas japonesas. In: ZOOTEC 2009, ASSOCIAÇÃO BRASILEIRA DE ZOOTECNISTAS, 5., Águas de Lindóia. Anais... Águas de Lindóia: ZOOTEC, 2009b. Available at: <http://www.abz.org.br> Accessed on: Apr. 14, 2011.

GARCIA, E.A.; MENDES, A.A.; PIZZOLANTE, C.C. et al. Protein, methionine + cystine and lysine levels for Japanese quails during the production phase. Poultry Science, v.7, n.1, p.11-18, 2005.

KIDD, M.T.; KERR, B.J. Dietary arginine and lysine ratios and electrolyte balance. Poultry Science, v.77, p.864-869, 1998.

MATOS, S.M.; LEANDRO, N.S.M.; STRINGHINI, J.H. et al. Níveis de lisina e treonina digestíveis para poedeiras comerciais Lohmann LSL de 24 a 44 semanas de idade. Acta Scientiarum. Animal Sciences, v.31, p.19-24, 2009. Available at: <http://www. periodicos.uem.> Accessed on: May 4, 2011
MOURA, G.S. Avaliação de dietas de diferentes densidades energéticas para codorna japonesa em postura. 2007. 80f. Dissertação (Mestrado em Zootecnia) - Universidade Federal de Viçosa, Viçosa, MG.

NATIONAL RESEARCH COUNCIL - NRC. Nutrient requirements of poultry. 9.ed. Washington: National Academy of Sciences, 1994. 155 p.

OLIVEIRA, A.M.; FURLAN, A.C.; MURAKAMI, A.E. et al. Exigência nutricional de lisina para codornas japonesas (Coturnix coturnix japonica). Revista Brasileira de Zootecnia, v.28, p.1050-1053, 1999.

OLIVEIRA, B.L. Importância do manejo na produção de ovos de codornas. In: SIMPÓSIO INTERNACIONAL DE COTURNICULTURA, 2., 2004, Lavras. Anais... Lavras: Núcleo de Estudos em Ciência e Tecnologia Avícolas, 2004. p.91-96.

OLIVEIRA, B.L. Manejo em granjas automatizadas de codornas de postura comercial. In: SIMPOSIO INTERNACIONAL, 3., e CONGRESSO BRASILEIRO DE COTURNICULTURA, 2., 2007, Lavras. Anais... Lavras, 2007. p.11-16.

PAULA, E.; BARRETO, S.L.T.; REIS, R.S. et al. Relação valina digestível com lisina digestível para codornas japonesas na fase de postura. In: "VIII CONGRESSO APA 2010", ASSOCIAÇÃO PAULISTA DE AVICULTURA, 3., 2010, São Pedro. Anais... São Pedro, 2010a. p.177-178.

PAULA, E.; BARRETO, S.L.T.; REIS, R.S. et al. Relação isoleucina digestível com lisina digestível para codornas japonesas em postura. In: SIMPÓSIO INTERNACIONAL, 4.; e CONGRESSO BRASILEIRO DE COTURNICULTURA, 3., 2010, Lavras. Anais... Lavras, 2010b. p.224.

PINHEIRO, S.R. Níveis de triptofano em dietas para codorna japonesa em postura. 2006. 61f. Dissertação (Mestrado em Zootecnia) - Universidade Federal de Viçosa, Viçosa, MG.

PINTO, R.; FERREIRA, A.S.; DONZELE, J.L. et al. Exigência de lisina para codornas japonesas em postura. Revista Brasileira de Zootecnia, v.32, p.1182-1189, 2003.

REIS, R.S.; UMIGI, R.T.; PINHEIRO, S.R. et al. Exigência nutricional de lisina para codornas européias em postura. In: CONGRESSO INTERNACIONAL DE ZOOTECNIA (ZOOTEC), 2006, Recife. Anais... Recife: Associação Brasileira de Zootecnia, 2006. Available at: <http://www.abz.org.br>. Accessed on: Apr. 22, 2011.

REIS, R.S. Relação metionina mais cistina com lisina em dietas para codornas japonesas em postura. 2009. 52f. Dissertação (Mestrado em Zootecnia) - Universidade Federal de Viçosa, Viçosa, MG.

REIS, R.S.; BARRETO, S.L.T.; PAULA, E.M. et al. Relação arginina digestível com lisina digestível para codornas japonesas na fase postura In: ZOOTEC, 2009, Águas de Lindóia. Anais... Águas de Lindóia: Associação Brasileira de Zootecnia, 2009. Available at: $<$ http://www.abz.org.br> Accessed on: Aug. 30, 2010.

RIBEIRO, M.L.G.; VILAR DA SILVA, J.H.; OLIVEIRA DANTAS, M. et al. Exigências nutricionais de lisina para codornas durante a fase de postura, em função do nível de proteína da ração. Revista Brasileira de Zootecnia, v.32, p.156-161, 2003.

RODRIGUES, V.P.; COSTA, F.G.P.; SILVA, J.H.V. et al. Exigência de lisina para codornas japonesas em produção. In: SIMPÓSIO INTERNACIONAL， 3.; e CONGRESSO BRASILEIRO DE COTURNICULTURA, 2., 2007, Lavras. Anais... Lavras, 2007. p.173. 
ROSTAGNO, H.S.; ALBINO, L.F.T.; DONZELE, J.L. et al. Tabelas brasileiras para aves e suínos. Composição de alimentos e exigências nutricionais. 2.ed. Viçosa, MG: Editora UFV, 2005. $186 \mathrm{p}$.

SILVA, D.J.; QUEIROZ, A.C. Análise de alimentos (Métodos químicos e biológicos). 3.ed. Viçosa, MG: Imprensa Universitária, 2002. 235p.

THOMPSON, R.; HAMILTON, R.M.G. Comparision of precision and accuracy of the flotation and archimedes' methods for measuring the specific gravity of eggs. Poultry Science, v.60, p.2388-2394, 1982.

UMIGI, R.T.; BARRETO, S.L.T.; MESQUITA FILHO, R.M. et al. Exigência de treonina digestível para codorna japonesa em postura. In: Reunião Anual da Sociedade Brasileira de Zootecnia, 45., 2008, Lavras. Anais... Sociedade Brasileira de Zootecnia, [2008]. (CD-ROM).

YANNAKOPOULOS, A.L.; TSERVENI-GOUSI, A.S. Quality characteristics of quail eggs. British Poultry Science, v.27, p.171-176, 1986. 